\title{
Irreversible Cholecystokinin-1 Receptor Antagonists Pnb-028/81: N-Isobutyl-5-Hydroxy-5-Aryl-Pyrrol-2- Ones as Experimental Therapeutic Agents against Colon and Pancreatic Cancer
}

\author{
E Lattmann ${ }^{1 *}$, ST Russell1ㅜ, PN Balaram², P Lattmann² and R Narayanan ${ }^{3}$ \\ ${ }^{1}$ School of Life and Health Sciences, Aston University, UK \\ ${ }^{2} P N B$ Vesper Life Science PVT, India \\ ${ }^{3}$ Department of Medicine, University of Tennessee Health Science Center, USA \\ *Corresponding author: E Lattmann, School of Life and Health Sciences, Aston University, England, UK \\ Submission: 監July 26, 2018; Published: 海 August 20, 2018
}

\begin{abstract}
A new class of 5-arylated 5-hydroxypyrrolones was derived from mucochloric acid in 2 synthetic steps and the chemical structure was confirmed additionally by $\mathrm{x}$-ray analysis. Using a radiolabelled binding assay, potent $\mathrm{CCK}_{1}$ selective ligands were identified $\left(\mathrm{CCK}_{1}: 12 \mathrm{nM}\right)$ and the antagonism was confirmed by using isolated tissue preparations. A series of isobutyl derivatives displayed insurmountable CCK antagonistic properties. Using electrically induced contractions and CCK induced contractions on isolated rat tissues, an irreversible antagonism was established. In vitro, using selected cancer cell lines, the viability was measured and IC-50 was obtained in the nanomolar range.

Using allograft models the treatment regimen was further optimised leading to a $48 \mathrm{~h}$ dosing interval. The downstream analysis revealed inhibition of proliferation analysed via the Ki 67 biomarker. Finally, using xenograft studies in nude mice, two selected pyrrolone derivatives, $\mathrm{X}=\mathrm{H}$ and $\mathrm{X}=\mathrm{F}$ a fluorinated analogue (PNB-028), showed a strong inhibition of tumour growth in a human pancreatic cell line (MIAPACA) at $50 \mathrm{mg} / \mathrm{kg}$ by oral administration. PK was analysed and the overall conclusion was drawn.
\end{abstract}

\section{Introduction}

Cholecystokinin (CCK) acts as a neuromodulator in the brain and as a gut hormone in the gastrointestinal tract. CCK-ligands, agonists as well as antagonists [1] have been extensively investigated as potential drug molecules [2]. Originally, cholecystokinin was discovered to cause contractions of the gallbladder, it was then rediscovered as pancreozymin, triggering the release of pancreatic enzymes and then, it was confirmed that both peptides are identical $[3]$.
Gastrin, closely related to cholecystokinin, triggers the release of gastric acid and in vitro in cell lines, gastric cancer is Gastin dependant [4]. Cholecystokinin does cause proliferation in colonand pancreatic cancer cell lines and therefore, CCK-antagonists were studied as growth factor inhibitors in certain forms of cancer [5]. They were evaluated as anxiolytics [6], in the treatment of schizophrenia [7], satiety [8] and reviewed as anxiolytics [9].

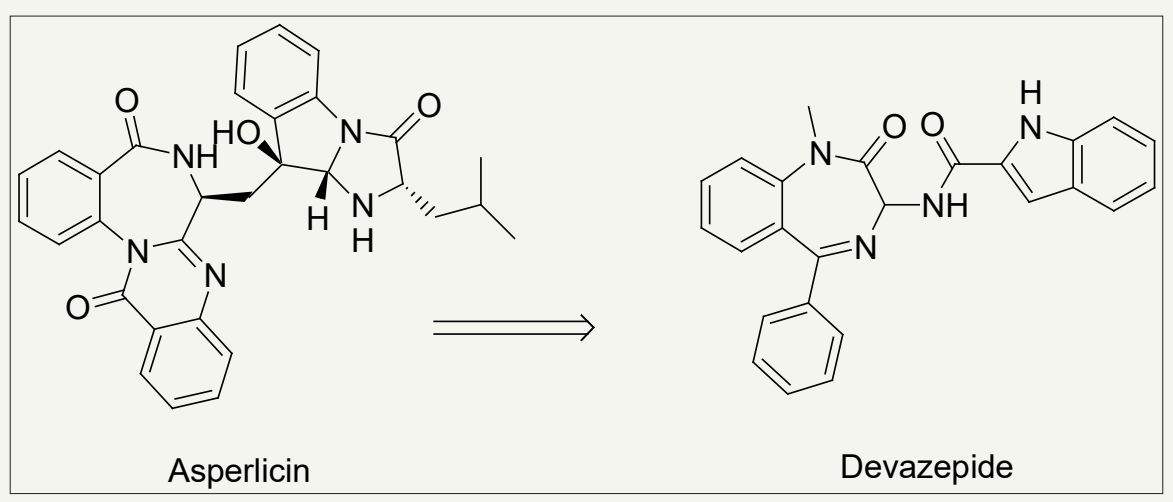

Figure 1: Drug design from natural product Asperlicin, towards fully synthetic Devazepide, a CCK1 selective antagonist. 
These properties may be beneficial in cancer patients in addition to their anti-neoplastic activity. Asperlicin (Figure 1) was the first non-peptidal CCK antagonist lead structure from nature and analogues thereof, were studies as CCK ligands [10]. Simplification of the lead structure by Merck led to Devazepide [11], a potent $\mathrm{CCK}_{1}$ selective cholecystokinin antagonist, containing a 1,4-benzodiazepine template and an indole moiety. Devazepide was tested clinically in 18 patients with advanced cancer [12] without escalating doses and failed to show significant effects due to its poor pharmacokinetic properties [13]
$\mathrm{Z}-360$ is a $\mathrm{CCK}_{2}$-Gastrin receptor antagonist and progressed into phase 2 trial with pancreatic cancer [14]. Pancreatic cancer (PDA) is an emerging disease and is the fourth leading cause of cancer death worldwide. The prognosis is very poor; the 5-year survival rate is $5 \%$, and the life expectancy of patients with metastatic PDA is approximately 2.8-5.7 months. These poor outcomes are likely due to resistance to chemotherapy and PDA biology. There are very limited options for patients with pancreatic cancer who have failed first line therapy and reflect the unmet need.

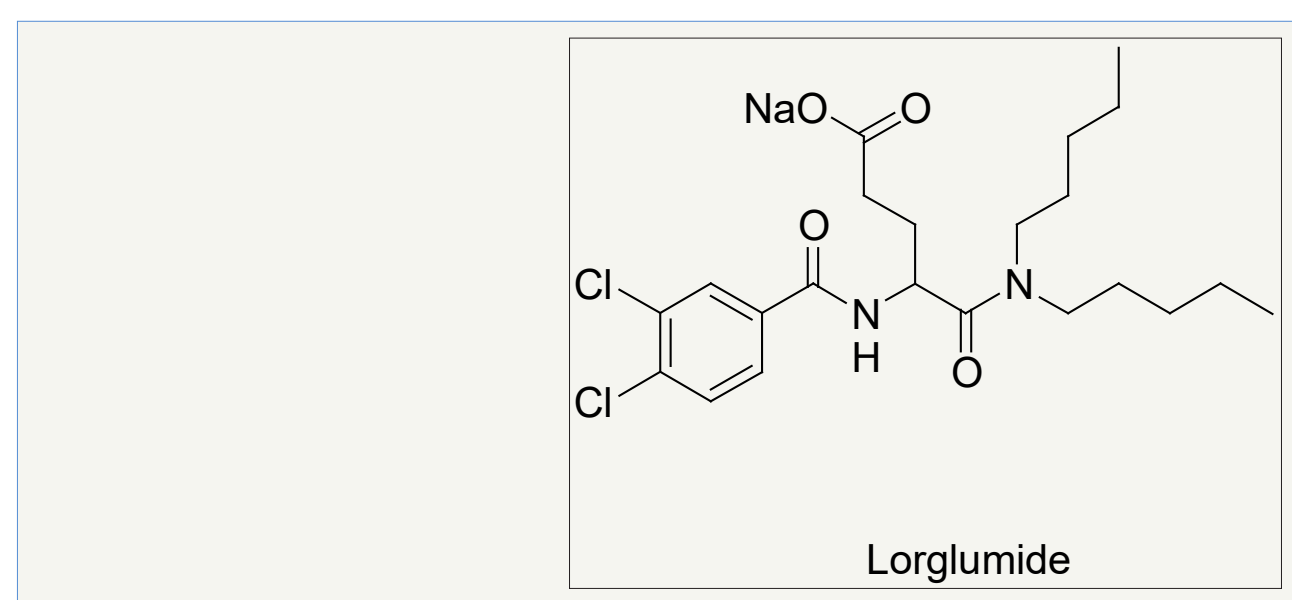

Figure 2: Lorglumide CCK standard.

Lorglumide (Figure 2) is 25 times more potent in blocking the cholecystokinin induced contractions of the gallbladder than proglumide, but the activity to block pancreatic amylase secretion is only better by factor 2 [15], indicating a heterogeneity of the $\mathrm{CCK}_{1}$ receptor. Proglumide with $\mathrm{mM}$ activity is too non-potent, requiring multi gramme quantities for potential cancer treatment [16-21].

Again, having realized the poor pharmacokinetic properties of these agents, a search for a completely novel, smaller template [22] with a molecular weight $<350$, a log p about 3 and a polar surface area for membrane penetration of less that $100 \mathrm{~A}$, with no urea linkage was initiated. Here, we identified within a novel chemical class, potent irreversible cholecystokinin antagonists, which translated in vitro and in vivo efficiency into new chemical entities (NCE) for the treatment of colon and pancreatic cancer.

\section{Materials and Methods}

\section{Synthesis}

The chemicals were obtained from Aldrich (Gillingham, UK) and Lancaster (Lancaster, UK). Atmospheric pressure chemical ionisation mass spectroscopy (APCI), negative or positive mode, was carried out using a Hewlett-Packard 5989b quadrupole instrument (Vienna, Austria). Proton and Carbon NMR spectra were obtained on a Bruker AC 250 instrument (Follanden, Switzerland), operating at $250 \mathrm{MHz}$, calibrated with the solvent reference peak or TMS. IR spectra were plotted from $\mathrm{KBr}$ discs on a Mattson 300FTIR Spectrometer. Melting points were recorded from a Stuart Scientific (Coventry, UK) Melting Point and are uncorrected.

\section{Synthesis of 3,4-dichloro-5-phenyl-5H-furan-2-one, Lac- tone A}

Dry and powdered aluminium chloride $(20 \mathrm{~g}, 0.15 \mathrm{~mol})$ was added slowly to a mixture of mucochloric acid (16.9g, $0.1 \mathrm{~mol})$ and benzene, fluorobenzene or chlorobenzene $(250 \mathrm{ml})$. The reaction mixture was stirred overnight. For work up it was poured into a mixture of $100 \mathrm{~g}$ ice and $32 \mathrm{ml}$ concentrated hydrochloric acid. The organic layer was separated by a separating funnel and it was washed with $3 \times 100 \mathrm{ml}$ of water. The combined organic layers were dried over magnesium sulphate and the solvent was removed under vacuum, the oily residue was crystallized in n-hexane.

Yield $=70 \%$, M.P: $78-79 \mathrm{C} ; \mathrm{R}_{\mathrm{f}}(80 \%$ ether $/ 20 \%$ petrol ether $)=0.62$; Molecular Weight: 229.1; Molecular Formula: $\mathrm{C}_{10} \mathrm{H}_{6} \mathrm{Cl}_{2} \mathrm{O}_{2}$; MS (APCI

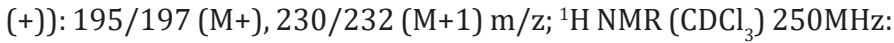
7.22-7.51 (m, 5H), 5.81 (CH) ppm. ${ }^{13} \mathrm{C}$ NMR 165.3, 152.2, 139.8, $130.5,129.3,128.5,127.4,127.2,121.2,83.5 p p m$. IR (KBr-disc) 3445, 3074, 3035, 2959, 2056, 1768, 1630, 1499, 1457 1294, 1224, $1028,910,772,705 \mathrm{~cm}^{-1}$.

\section{3,4-Dichloro-5-(4-chloro-phenyl)-5H-furan-2-one, Lac- tone B}

Yield $=69 \%$ M.P: $76-78{ }^{\circ} \mathrm{C} ; \mathrm{R}_{\mathrm{f}}(80 \%$ ether / $20 \%$ petrol ether) $=0.55$; Molecular Weight: 263.5; Molecular Formula: $\mathrm{C}_{10} \mathrm{H}_{5} \mathrm{Cl}_{3} \mathrm{O}_{2} ;$ MS (APCI(+)): 227/229/231 (M+1), 262/263/265 $(\mathrm{M}+) \mathrm{m} / \mathrm{z} ;{ }^{1} \mathrm{H}$ NMR $\left(\mathrm{CDCl}_{3}\right) 250 \mathrm{MHz}$ : 7.42-7.55 (m, 2H), 7.28-7.40 (m, 2H), $5.91(\mathrm{CH}) \mathrm{ppm} .{ }^{13} \mathrm{C}$ NMR $\left(\mathrm{CDCl}_{3}\right)$ 165.3, 152.0, 136.6, 130.1, 129.6, 128.7, 121.3, 82.9p pm. IR (KBr-disc) 3451, 3075, 2952, 2051, $1769,1636,1497,1419,1289,1231,1027,927,826,748,720 \mathrm{~cm}^{-1}$. 


\section{3,4-Dichloro-5-(4-fluoro-phenyl)-5H-furan-2-one, Lac- tone $\mathrm{C}$}

Yield $=79 \%$ M.P: $74-76{ }^{\circ} \mathrm{C} ; \mathrm{R}_{\mathrm{f}}(80 \%$ ether $/ 20 \%$ petrol ether) =0.53; MS (APCI(+)): 227/229/231 (M+1), 247, $246(\mathrm{M}+) \mathrm{m} / \mathrm{z} ;{ }^{1} \mathrm{H}$ NMR $\left(\mathrm{CDCl}_{3}\right)$ 250MHz: 7.42-7.55 (m,2H), 7.28-7.40 (m,2H), 5.91 (CH)ppm. ${ }^{13} \mathrm{C}$ NMR $\left(\mathrm{CDCl}_{3}\right)$ 250MHz: 165.2, 152.0, 136.6, 130.1, 129.6, 128.7, 121.3, 82.8 ppm. IR (KBr-disc) 3451, 3075, 2952, 2051, 1769, 1636, 1497, 1419, 1289, 1231, 1027, 927, 826, 748, $720 \mathrm{~cm}^{-1}$.

\section{General Method}

Isobutyl amine in 2.5 times excess was added to a solution of Lactone $\mathrm{A}, \mathrm{B}$, or $\mathrm{C}(0.7 \mathrm{~mol})$ in ether $(10 \mathrm{ml})$ and the reaction mixture was stirred on ice for 30 minutes, allowing to warm up to RT over time. The resultant mixture was poured into $15 \mathrm{ml}$ water and the organic phase was separated by a separating funnel. The mixture was subsequently washed with an excess of water for three more times. The organic layer was dried over magnesium sulphate and the solvent was removed under vacuum. All compounds gave an oily solid on a small scale, which was purified using column chromatography with a mixture of $80 \%$ ether $/ 20 \%$ petrol ether to yield crystals after removal of the solvent in vacuum.

\section{4-Chloro-5-hydroxy-1-isobutyl-5-phenyl-1,5-dihydro- pyrrol-2-one PNB-081}

Yield=85\%; MP: $167-169{ }^{\circ} \mathrm{C} ; \mathrm{R}_{\mathrm{f}}$ (80\% ether $/ 20 \%$ petrol ether)=0.27; Molecular Weight: 264.7; Molecular Formula: $\mathrm{C}_{14} \mathrm{H}_{16} \mathrm{ClNO}_{2 ;}$ MS(APCI(+)): 193/195(M+1), 266/268(M+)m/z; ${ }^{1} \mathrm{HNMR}\left(\mathrm{CDCl}_{3}\right)$ 250MHz: 7.38-7.51(m,5H), 6.24(s,CH), 4.79-4.98 (bs,OH), 3.23-3.32 \& 2.18-2.29 (dd,2H), 1.71-1.90(m,1H) 0.760.96(m, 6H)ppm. ${ }^{13} \mathrm{C} \mathrm{NMR}\left(\mathrm{CDCl}_{3}\right)$ 168.5, 155.7, 137.1, 129.2, 128.7, 126.2 (5xArC), 121.7, 93.1, 47.6, 27.5, 20.4ppm. IR (KBr-disc): 3237 , 3114, 2965, 2926, 2881, 2374, 2343, 1675, 1614, 1460, 1416, 1299, $1251,1202,1150,1072,1027,878,758,696 \mathrm{~cm}^{-1}$ (Table $1 \& 2$ ).

Table 1:

\begin{tabular}{|c|c|}
\hline \multicolumn{2}{|c|}{ Crystal Data - (Sample Recrystallised from Methanol) } \\
\hline $\mathrm{C}_{28} \mathrm{H}_{32} \mathrm{Cl}_{2} \mathrm{~N}_{2} \mathrm{O}_{4}$ & $\mathrm{~V}=1371.5(5) \AA^{3}$ \\
\hline $\mathrm{M}_{\mathrm{r}}=531.46$ & $\mathrm{Z}=2$ \\
\hline $\mathrm{T}=293(2) \mathrm{K}$ & $\mathrm{D}_{\mathrm{x}}=1.287 \mathrm{Mg} / \mathrm{m}^{-3}$ \\
\hline Tabular & $\mathrm{D}_{\mathrm{m}}$ not measured \\
\hline $0.20 \times 0.15 \times 0.10 \mathrm{~mm}$ & $\mathrm{R}\left[\mathrm{F}^{2}>2\left(\mathrm{~F}^{2}\right)\right]=0.0541$ \\
\hline Colourless & $\mathrm{wR}\left(\mathrm{F}^{2}\right)=0.1165$ \\
\hline $\mathrm{MK} \alpha$ radiation: $\lambda=0.71073 \AA$ & 5136 reflections \\
\hline Triclinic & 331 parameters \\
\hline $\mathrm{P}-1$ & \\
\hline $\mathrm{a}=8.3190(13) \AA$ & \\
\hline $\mathrm{b}=12.614(4) \AA$ & \\
\hline $\mathrm{c}=13.8106(18) \AA$ & \\
\hline &
\end{tabular}

\begin{tabular}{|c|l|}
\hline$\alpha=93.049(17)^{\circ}$ & \\
\hline$\beta=94.791(12)^{\circ}$ & \\
\hline$\Upsilon=107.651(19)^{\circ}$ & \\
\hline
\end{tabular}

Table 2: Selected geometric parameters $\left.(\AA ̊,)^{\circ}\right)$.

\begin{tabular}{|c|c|c|c|}
\hline $\mathrm{Cl}(1)-\mathrm{C}(1)$ & $1.696(4)$ & $\mathrm{Cl}\left(1^{\prime}\right)-\mathrm{C}\left(1^{\prime}\right)$ & $1.695(4)$ \\
\hline $\mathrm{C}(1)-\mathrm{C}(4)$ & $1.310(5)$ & $\mathrm{C}\left(1^{\prime}\right)-\mathrm{C}\left(4^{\prime}\right)$ & $1.322(5)$ \\
\hline $\mathrm{C}(2)-\mathrm{C}(5)$ & $1.511(5)$ & $\mathrm{C}\left(2^{\prime}\right)-\mathrm{C}\left(5^{\prime}\right)$ & $1.524(5)$ \\
\hline $\mathrm{C}(2)-\mathrm{O}(2)$ & $1.410(4)$ & $\mathrm{C}\left(2^{\prime}\right)-\mathrm{O}\left(2^{\prime}\right)$ & $1.400(4)$ \\
\hline $\mathrm{C}(3)-\mathrm{O}(1)$ & $1.224(5)$ & $\mathrm{C}\left(3^{\prime}\right)-\mathrm{O}\left(1^{\prime}\right)$ & $1.237(4)$ \\
\hline $\mathrm{N}(1)-\mathrm{C}(11)$ & $1.448(5)$ & $\mathrm{N}(1)-\mathrm{C}(11)$ & $1.448(5)$ \\
\hline
\end{tabular}

\section{4-Chloro-5-(4-fluoro-phenyl)-5-hydroxy-1-isobutyl-1,5- dihydro-pyrrol-2-one PNB-028}

Yield=86\%; Melting Point: $158-159{ }^{\circ} \mathrm{C} ; \mathrm{R}_{\mathrm{f}}(80 \%$ ether / $20 \%$ petrol ether) $=0.21$; Molecular Weight: 284.2; Molecular Formula: $\mathrm{C}_{14} \mathrm{H}_{15} \mathrm{ClFNO}_{2 ;} \quad \mathrm{MS}(\mathrm{APCI}(+)): \quad 211 / 212(\mathrm{M}+1), \quad 284 / 285(\mathrm{M}+)$ $\mathrm{m} / \mathrm{z} ;{ }^{1} \mathrm{H}$ NMR $\left(\mathrm{CDCl}_{3}\right)$ 250MHz: 7.30-7.41 (m,4H), 6.19(s,1H), 3.13-3.31(dd,1H), 2.49-2.62(dd, $\left.\mathrm{CH}_{2}, \quad \mathrm{~J}=8.0 \mathrm{~Hz}, \quad 1 \mathrm{H}\right), \quad 1.69-1.83$ $\left.(\mathrm{m}, 1 \mathrm{H}), 0.69-0.80\left(\mathrm{t}, \mathrm{CH}_{3}, \mathrm{~J}=4.5 \mathrm{~Hz}, 6 \mathrm{H}\right) \mathrm{ppm} .{ }^{13} \mathrm{CNMR}_{\left(\mathrm{CDCl}_{3}\right)}\right) 163.6$, 156.1, 139.0, 134.7, 129.0, 127.2, 122.1, 95.0, 47.1, 27.2, 20.5ppm IR (KBr-disc) 3425, 3251, 2964, 2924, 2850, 1685, 1406, 1209 , $1095,816,743 \mathrm{~cm}^{-1}$.

\section{4-Chloro-5-(4-chloro-phenyl)-5-hydroxy-1-isobutyl-1,5- dihydro-pyrrol-2-one Cl-lactam}

Yield $=76 \%$; Melting Point: $155-158{ }^{\circ} \mathrm{C} ; \mathrm{R}_{\mathrm{f}}(80 \%$ ether $/ 20 \%$ petrol ether) $=0.22$; Molecular Weight: 300.2; Molecular Formula: $\mathrm{C}_{14} \mathrm{H}_{15} \mathrm{Cl}_{2} \mathrm{NO}_{2 ;} \mathrm{MS}(\mathrm{APCI}(+)): 227 / 229 / 231(\mathrm{M}+1), 300 / 302 / 304(\mathrm{M}+)$ $\mathrm{m} / \mathrm{z} ;{ }^{1} \mathrm{H}$ NMR $\left(\mathrm{CDCl}_{3}\right)$ 250MHz: 7.30-7.41(m,4H), 6.19(s,1H), 3.13-3.31(dd, $\left.\mathrm{CH}_{2}, \mathrm{~J}=8.0 \mathrm{~Hz}, 1 \mathrm{H}\right), 2.49-2.62\left(\mathrm{dd}, \mathrm{CH}_{2}, \mathrm{~J}=8.0 \mathrm{~Hz}, 1 \mathrm{H}\right)$, $1.69-1.83(\mathrm{~m}, \mathrm{CH}, \mathrm{J}=5.8 \mathrm{~Hz}), 0.69-0.80\left(\mathrm{t}, \mathrm{CH}_{3}, \mathrm{~J}=4.5 \mathrm{~Hz}, 6 \mathrm{H}\right) \mathrm{ppm} .{ }^{13} \mathrm{C}$ NMR (CDCl ${ }_{3}$ ) 163.3, 156.3, 139.4, 134.8, 129.1, 127.7, 122.3 , 95.0, 47.6, 27.6, 20.4ppm IR (KBr-disc) 3426, 3252, 2964, 2924, 2850, $1684,1406,1209,1095,817,743,703 \mathrm{~cm}^{-1}$.

\section{[125]I-CCK-8 Radio ligand cholecystokinin binding as- say}

$\mathrm{CCK}_{2}$ and $\mathrm{CCK}_{1}$ receptor binding assays were performed, by using guinea pig cerebral cortex or rat pancreas. Male guinea pig brain tissues were prepared according to the modified method described by pancreatic membranes were prepared. Tissues were homogenized in ice cold sucrose $(0.32 \mathrm{M}, 25 \mathrm{ml})$ for 15 strokes at $500 \mathrm{rpm}$ and centrifuged at $13000 \mathrm{rpm}$ for 10 minutes. The supernatant was re-centrifuged at $13000 \mathrm{rpm}$ for 20 minutes. The resulting pellet was re-dispersed to the required volume of buffer at $500 \mathrm{rpm}$ and stored in aliquots at $70^{\circ} \mathrm{C}$. 
Binding was achieved using radio ligand ${ }^{125}$ I-Bolton-Hunter labeled CCK, NEN at 25pM. The samples were incubated with membranes $(0.1 \mathrm{mg} / \mathrm{ml})$ in $20 \mathrm{mM}$ Hepes, $1 \mathrm{mM}$ EGTA, $5 \mathrm{mM} \mathrm{MgCl}_{2}$, and $150 \mathrm{mM} \mathrm{NaCl}$, at $\mathrm{pH} 6.5$ for $2 \mathrm{hrs}$ at RT and then centrifuged at $11000 \mathrm{rpm}$ for 5 minutes. The membrane pellets were washed twice with water and the bound radioactivity was measured in a Packard Cobra Auto-gamma counter (B5005), Binding assays were carried out with L-363, 260 as control.

\section{Isolated tissue preparations}

Male Sprague Dawley rats, weighing 200-250g were used and all animal care and experimental protocols adhered to the relevant laws and guidelines of the institution. The animals were housed under standard conditions of temperature $\left(25^{\circ} \mathrm{C}\right)$ with unrestricted access to food and water. The animals were sacrificed using cervical dislocation without anaesthesia. From the abdomen of the animals, the duodenum was carefully excised and washed with physiological solution. The mesentery of the tissue was removed and the lumen was gently flushed with Tyrode's solution to clear luminal contents. The prepared isolated tissue was rapidly incubated in Tyrode's solution maintained at $32{ }^{\circ} \mathrm{C}$ and gassed with $95 \% \mathrm{O}_{2} / 5 \% \mathrm{CO}_{2}$.

Tyrode's solution was freshly prepared daily (g/l): $\mathrm{NaCl}, 8.0$; $\mathrm{KCl}, 0.2 ; \mathrm{CaCl}_{2}, 0.2 ; \mathrm{MgSO}_{4}, 0.1 ; \mathrm{NaH}_{2} \mathrm{PO}_{4}, 0.05 ; \mathrm{NaHCO}_{3}, 1.0$; Glucose, 1.0. The main equipment used was the Radnoti single unit tissue bath system with a chamber capacity of $35 \mathrm{ml}$. Bath aeration with carbogen $\left(\mathrm{O}_{2} 95 \%, \mathrm{CO}_{2} 5 \%\right)$ was maintained at a constant temperature $\left(32{ }^{\circ} \mathrm{C}\right)$. The force in grams was measured with an isometric transducer linked to a power lab data acquisition system.

Electrically stimulated muscle contractions the intramural nerves within the ileal strips were excited by rectangular pulses of $2 \mathrm{~ms}, 25 \mathrm{~mA}$ and a frequency of $0.2 \mathrm{~Hz}$ Transmural stimulation was applied using two platinum electrodes, one placed in the lumen of the ileum and the other outside the tissue. CCK-5, penta- Gastrin and cholecystokinin CCK-8 preparations CCK-8S was dissolved in distilled water to prepare a stock solution of $500 \mu \mathrm{M}$ solution, from which cumulative additions of increasing concentrations $(0.1 \mathrm{nM}$, $1 \mathrm{nM}, 5 \mathrm{nM}, 10 \mathrm{nM}, 20 \mathrm{nM}, 30 \mathrm{nM}$, and $40 \mathrm{nM}$ ) were tested to plot a dose response curve. Test molecules and lorglumide were added to the organ bath 10 minutes before exposure to the next CCK-8S serial concentrations. The same protocol was used for pentagastrin, CCK-5.

\section{Molecular modeling}

For target preparation the protein structures, pdb identifier $1 \mathrm{HZN}$ for the $\mathrm{CCK}_{1}$ and $1 \mathrm{~L} 4 \mathrm{~T}$ for the $\mathrm{CCK}_{2}$-Gastrin receptor were downloaded from the protein data bank (www.rcs.org) and docking was performed using Autodock Vina and Hex. After several docking trials for the $\mathrm{CCK}_{1} / \mathrm{CCK}_{2}$ receptor the results were analysed and visualized using Chimera and Designer studio 4.5. After visual inspection the results were presented to rationalize drug ligand interactions with the each CCK receptor subtype.

\section{Allograft study}

In vivo experiments in mice - assessment of anti-tumor inhibition: Pure strain NMRI mice aged between 6 and 8 weeks from our inbred colony were used for transplanting MAC (murine colon cancer) tumours. Animals were fed on RM3E diet (Lillco-England) and water ad libitum. Approximately $2 \mathrm{~mm}$ cubes containing $2 \times 10^{5}$ cells of MAC 16 tumor fragments were transplanted subcutaneously in the inguinal region via a trocar in a volume of $0.2 \mathrm{ml}$. Tumour bearing mice were randomized in groups of 7 animals per group and the treatment was started 10 days after transplantation. The test compounds were administered in propylene glycol. The effect of chemotherapy was assessed 20days after transplantation. Mice were killed after 10 days of drug treatment and the effects were measured by the differences in tumor weight as expressed: $\%[$ inhibition]=Treated weight/control weightx100. The body weight changes were recorded additionally. The procedure was approved by the home office and the bioethics committee of Aston University.

Xenograft study in NSG mice: 1 million cells were used per mouse and the test molecule was administered in 20\% DMS0+80\% PEG-300. The suspension was vortexes and warmed at $37{ }^{\circ} \mathrm{C}$ for 5 min to ensure dissolution. MAC 16 mouse chemo resistant colon cancer cells were grown in RPMI medium supplemented with $10 \%$ fetal bovine serum (FBS) in $37{ }^{\circ} \mathrm{C}$ incubator with $5 \% \mathrm{CO}_{2}$. Human cancer cells were grown in DMEM supplemented with $10 \%$ FBS in $37^{\circ} \mathrm{C}$ incubator with $5 \% \mathrm{CO}_{2}$. Cells were grown until $70 \%$ confluence before pass aging into fresh flasks. For xenograft implantation, above indicated cells were harvested, viable cells determined by trypan blue exclusion, and a cell suspension in growth medium was prepared. The cell suspension in growth medium (100$111 /$ mouse) was implanted subcutaneously in NSG mice. Once tumours reached $100 \mathrm{~mm}^{3}$, the animals were randomized within the respective cell line and treated orally. Body weight and tumour volume were measured thrice weekly (Mon, Wed, and Fri). Animals were sacrificed (6hrs after the last dose) when the tumours reached over $1500 \mathrm{~mm}^{3}$ or when the animals lost over $20 \%$ body weight. All experiments were performed in compliance with the relevant laws and institutional guidelines and the institutional bioethics committee has approved the experiments.

PK analysis: 6-8 week male rats purchased from Harlan Research Laboratories, North America Registration Number: Syngene-IAEC-412-08-2013 aged 6 to 8 weeks old Identification: They were identified individually with tail marking using permanent marker Acclimatization: At least for one week under laboratory conditions, after veterinary examination. Only animals without any visible signs of illness were used for the study. Time points for blood sampling (IV dose) were pre-dose, 0.083, 0.25, $0.5,1,2,4,6,8, \& 24 \mathrm{hr}$ post dose (10 time points). Time-points for blood collection (PO dose) were, pre-dose, $0.25,0.5,1,2,4,6,8$, \& $24 \mathrm{hr}$ post dose ( 9 time points). At each time point, approximately $150 \mu \mathrm{L}$ of blood was collected through jugular vein in labeled tubes containing K2-EDTA as anticoagulant. The tubes were mixed gently and centrifuged at $2500 \mathrm{~g}$ for 10 minutes at $4{ }^{\circ} \mathrm{C}$. The plasma was separated into labeled polypropylene tubes $(\sim 75 \mu \mathrm{l}$ of plasma $)$ and stored immediately at $-80^{\circ} \mathrm{C}$ until analysis.

Analysis of samples by LC-MS/MS was done using API Sciex 4000 system operated with Nexera ${ }^{\mathrm{TM}}$ UHPLC (Shimadzu) as front- 
end. Samples were separated on a Phenomenex kinetex C18 $(50 \times 2.1 \mathrm{~mm}, 5 \mu)$ using a gradient mode at a flow rate of $1 \mathrm{ml} / \mathrm{min}$. The mobile phase consisted of $0.1 \%$ formic acid in MilliQ water (A) and $0.1 \%$ formic acid in acetonitrile (B). MS instrument was operated in positive mode. The multiple reactions monitoring transition of test molecule was 247.9/192.0 (Q1/Q3) with a declustering potential of $70 \mathrm{~V}$, entrance potential $10 \mathrm{~V}$, and collision energy of $25 \mathrm{~V}$. The

\section{Results and Discussion}

\section{Chemistry}

curtain gas $(5 \mathrm{~V})$, ion-spray voltage $(5500 \mathrm{~V})$, temperature $\left(500^{\circ} \mathrm{C}\right)$, nebulizer gas (GS1), and auxiliary gas (GS2) were set at 45psi \& $55 p s i$ respectively, and the interface heater was on.

Statistical methods: The data were expressed as mean \pm SD and one-way analysis of variance (ANOVA) and supplementary Turkey test for pair wise comparison were tested to determine for any significant difference at $\mathrm{p}<0.05$.

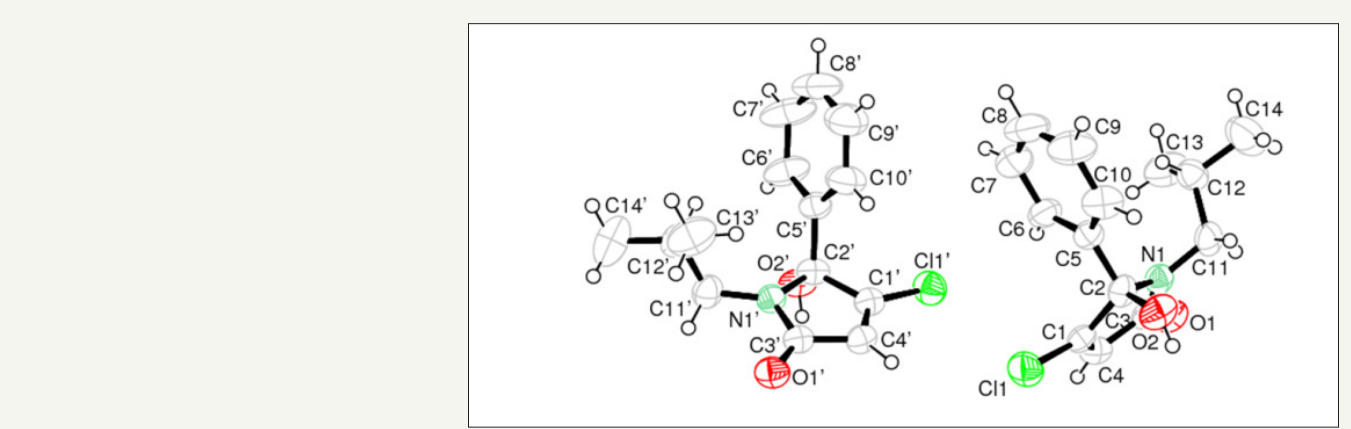

Figure 3: X-ray structure of 4-Chloro-5-hydroxy-1-isobutyl-5-phenyl-1,5-dihydro-pyrrol-2-one, PNB-081 re crystallised from methanol.

The arylated dichloro-2(5H)-furanones (Lactone A, B, C) were synthesised from mucochloric acid, which is available from furfural under oxidising conditions with hydrochloric acid. Theses arylated intermediates were chemically optimised by us previously and evaluated as anticancer agents [23]. Under mild conditions, using ether as solvent, the arylated furanones were reacted with isobutyl amine, required for best SAR towards the $\mathrm{CCK}_{1}$ receptor. The experimental details are described in materials and methods and no acyclic ketone, the ring opened form of the hydroxyl-pyrrolone, was observed. On a small scale purification was performed by column chromatography and on a multi gramme scale, the isobutyl series was purified by recrystallisation with methanol. As the gold standard of structure characterisation, the x-ray structure of PNB081was determined and is displayed in Figure 3. The molecule is not present in a keto form and fully occurred in the 5-membered ring form, as a hydroxyl-pyrrolone.

\section{SAR optimisation}

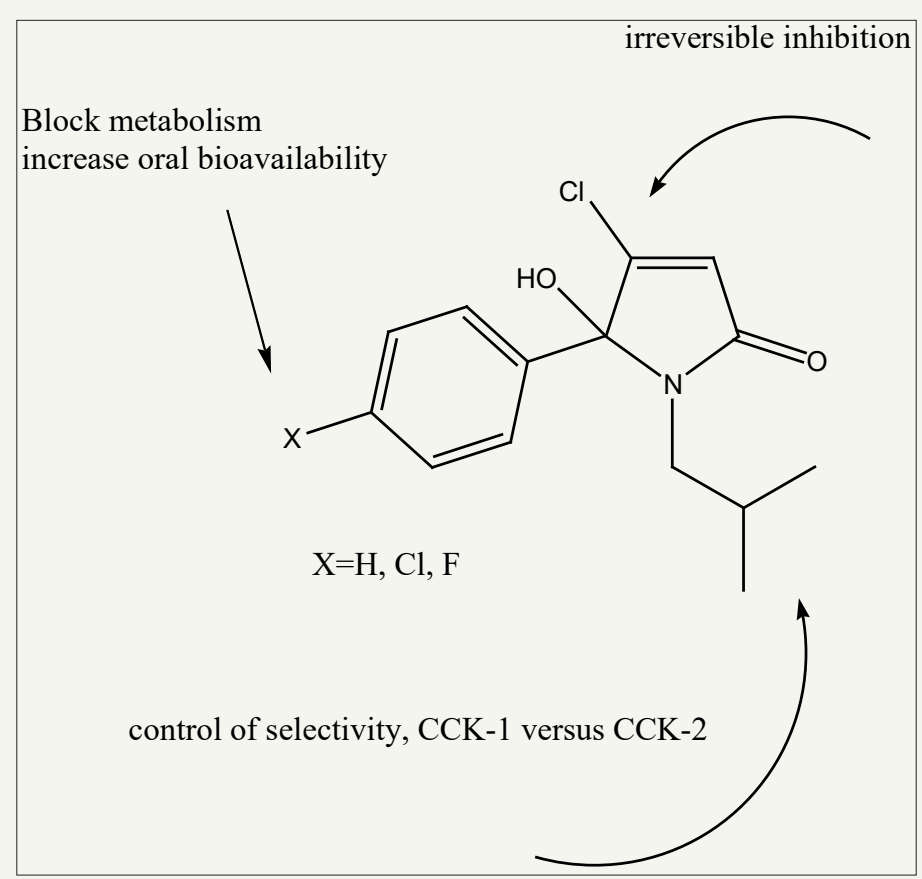

Figure 4: Selected key features of isobutyl-lactams. 
Table 3: CCK binding affinity using Radio Ligands with cortex and pancreatic membranes IC50 is presented in Micro molar; $\mathrm{N}=3$.

\begin{tabular}{|c|c|c|c|c|}
\hline Pyrrolone & $\mathbf{X}=$ & $\mathbf{R}=$ & $\begin{array}{c}\text { CCK-A } \\
{[\mu \mathbf{M}]}\end{array}$ & $\begin{array}{c}\text { CCK-B } \\
{[\mu \mathbf{M}]}\end{array}$ \\
\hline PNB-081 & H & Isobutyl & $0.020 \pm 0.01$ & $1.2 \pm 0.3$ \\
\hline PNB-028 & F & Isobutyl & $0.012 \pm 0.01$ & $0.75 \pm 0.2$ \\
\hline Cl- lactam & $\mathrm{Cl}$ & Isobutyl & $0.008 \pm 0.01$ & $0.4 \pm 0.2$ \\
\hline Lorglumide & - & - & $0.17 \pm 0.01$ & $>10$ \\
\hline
\end{tabular}

The initial step of evaluation was to screen for potent binding affinity and to identify a $\mathrm{CCK}_{1}$ selective ligand for the treatment of cholecystokinin related conditions. Using radiolabel iodinated cholecystokinin, inhibition of binding was determined for all test molecules and the $\mathrm{IC}_{50}$ are outlined in Table 3 . The change from a propyl into a butyl group resulted in a manifold increase of activity and the best substituent was found isobutyl, as shown in Figure 4 for the iso-butyl series 9-11. The introduction of a halogen atom resulted in an increase of binding affinity, possibly due to enhanced Lipophilicity and the best overall molecule is pyrrolone with an $\mathrm{IC}_{50}$ about 8nM. The t-butyl analogue was formed in very low yields, same as a pentyl analogue (not included).

Generally, within the isobutyl series the halogen atom on the 5-arylated ring enhanced the binding affinity. The $\mathrm{IC}_{50}$ was enhanced from 20nM for PNB-081, towards the 10nM range for the halogenated entities. Most importantly the metabolism, such as an expected hydroxylation in the Para-phenyl position, would be blocked, resulting in agents with improved pharmacokinetic properties. Under Electrophilic catalysis the Michael position should allow the formation of a covalent bond leading to irreversible CCK inhibitors. Molecular modelling studies were performed to rationalise drug receptor interactions of the Cl-lactam with the $\mathrm{CCK}_{1}$ receptor.

The isobutyl group of the ligand interacted with a hydrophobic cave of the receptor, centred at Ala-14. The carbonyl group in the 2-position bond via hydrogen binding towards the CCK receptor with Arg-9 and the N- atom of the lactam interacted with Glu-17. The 5-hydroxyl group of the lactam ligand displayed interactions with of Asn-6, which are outlined in Figure 5. The phenyl group has no interaction with tryptophan or phenylalanine and Pi - alkyl interactions of the chloro-phenyl group with Leu-29 and Ile-28 explain the small increase in specific binding. The ligand acted as irreversible inhibitor in vitro and the $3^{\text {rd }}$ extracellular loop of the $\mathrm{CCK}_{1}$ receptor with the natural ligand $\mathrm{CCK}_{8 \mathrm{~s}}$ binding site was selected to initiate modelling. It was assumed that irreversible, possibly covalent interaction with this loop of the receptor may deform the site and explain the superiority of the antineoplastic activity of this class of agents compared with competitive inhibitors.

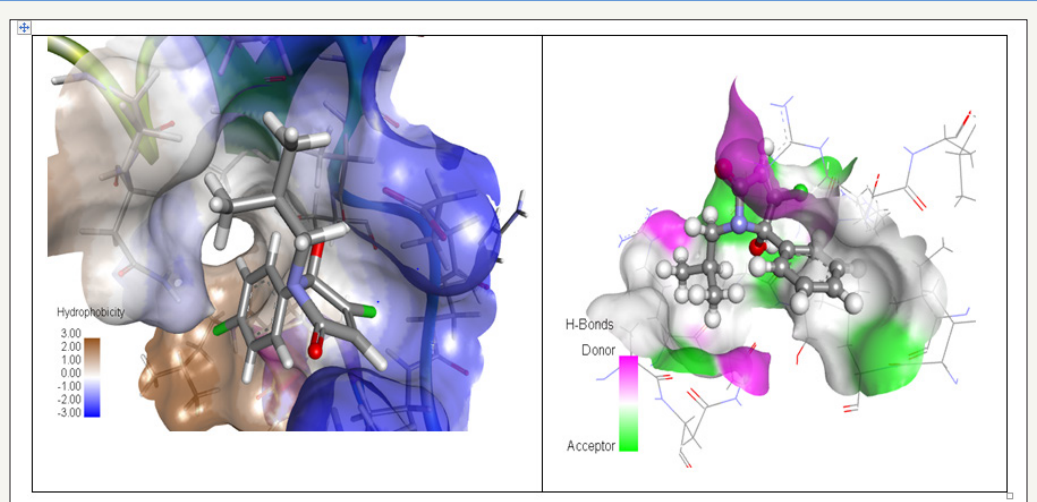

Figure 5: Drug receptor interactions of $\mathrm{Cl}$-lactam with the $\mathrm{CCK}_{1}$ receptor.

\section{Pharmacology}

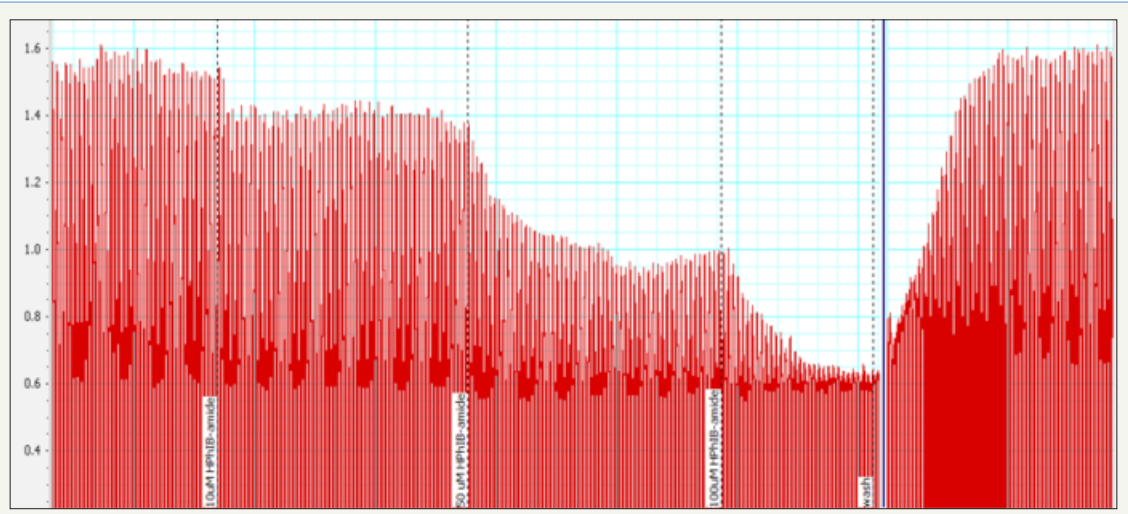

Figure 6: The inhibitory effect of $0.1,0.5$ and $1.0 \mu \mathrm{M}$ of isobutyl-Pyrrolone on electrically stimulated rat duodenum tissue contractions. 
Opiate agonists, such as morphine and CCK antagonists, such as lorglumide and Devazepide reduced electrically induced contractions on the GPI. From the radio ligand binding assay the iso-butyl-pyrrolone were identified as the most potent ligands, and the classical isolated tissue preparation served as initial functional assay, confirming the antagonistic properties of these ligands. Using the isolated rat duodenum preparation, a stable amplitude was generated and a reduction of this amplitude was observed dose dependently for the isobutyl series, which is outlined in Figure 6 for the isobutyl lactam. This assay represents a fast and efficient way to screen for CCK antagonists using classical isolated tissue preparations.

Cholecystokinin, $\mathrm{CCK}_{8 \mathrm{~s}^{\prime}}$ induced contractions of the guinea pig gall bladder and this second tissue based assay was applied to reconfirm with this standard preparation the antagonistic properties of the potent CCK ligands. CCK-8s induced contractions of the gall bladder and these contractions were reduced dose dependently, which is outlined for the PNB molecule in Figure 7. The concentration - response curve was calculated based on the percentage response to $10^{-5} \mathrm{M}$ ACh for a better comparison. Increased concentrations of the antagonist were added to the bath cumulatively and a shift of the curve to the right was observed. The function of the halogen atom is to enhance binding affinity/increase Lipophilicity and most importantly, to block metabolism of the molecules in the Para - phenyl position. It appeared that the effect of the antagonist in the gallbladder assay is insurmountable and an irreversible inhibitor is ideal for the development of antineoplastic agents. Reactive chlorine in the 4-position may be suitable for covalent drug receptor interactions, explaining an irreversible antagonism for the isobutyl- pyrrolone series. The antineoplastic properties of selected NCE and standard CCK antagonists, such as L-365,260 $\left(\mathrm{CCK}_{2}\right)$, Devazepide and lorglumide $\left(\mathrm{CCK}_{1}\right)$ was subsequently investigated, using a range of CCK associated cancer cell lines.

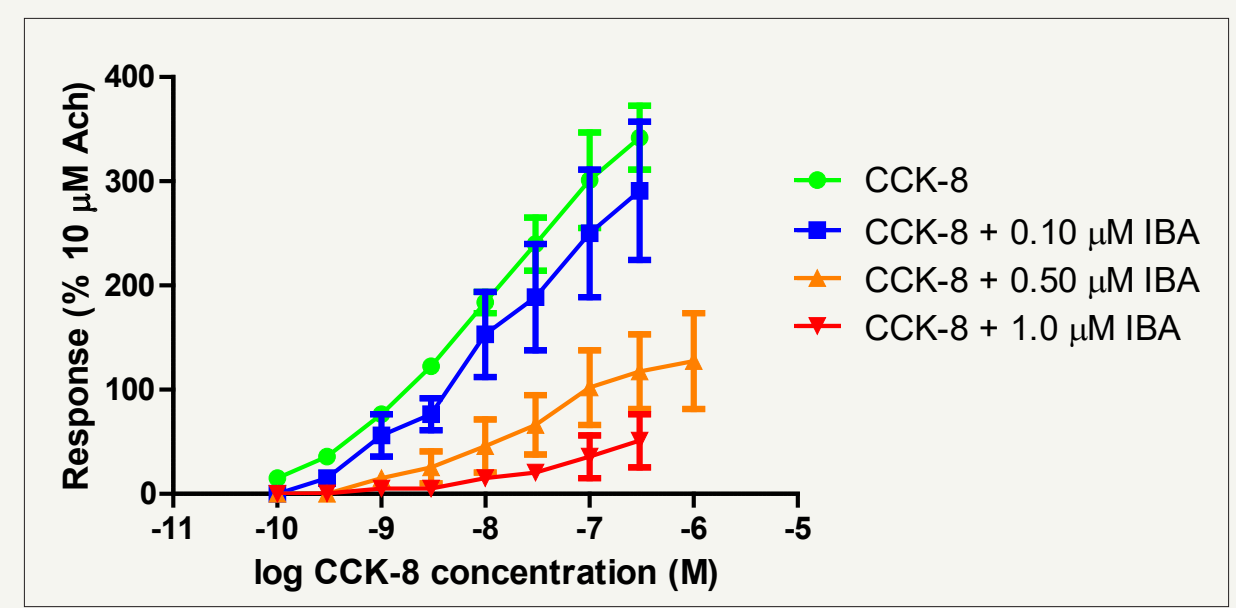

Figure 7: Mean cumulative concentration-response curve for CCK-8s in the absence and presence of $0.1,0.5$ and $1.0 \mu \mathrm{M}$ lactam determined for the isolated guinea pig gallbladder (Internal standard: ACh $10 \mu \mathrm{M}=100 \%$ contraction.

\section{In vitro cancer cell based testing}

CCK antagonists are associated with an array of therapeutic applications, but the focus of our research programme was to provide a non-toxic orally available CCK antagonist for the treatment of cancers.

\section{In vitro tests - Cytotoxicity assays}

In vitro tests were originally performed using a cell countassay, as the aim was to inhibit proliferation and not to optimise cytotoxicity, but the results were identical in the methylthiazolyltetrazolium (MTT) assay, possible due to induced apoptosis. It was screened for an inhibitor of viability in certain CCK related cancers cell lines using the MTT assay. MIA PACA: Miapaca is a human pancreatic carcinoma cell line and selected data are outlined in Table 4. The isobutyl pyrrolone was found 20 times better in terms of $\mathrm{IC}_{50}$ concentrations than lorglumide. Devazepide, which gave an $\mathrm{IC}_{50}$ about $1 \mu \mathrm{M}$ showed agonistic activity (unpublished results). Lorglumide, a $\mathrm{CCK}_{1}$ antagonist, was acting on the gallbladder $\mathrm{CCK}_{1}$ receptor and not the pancreatic CCK receptor. None of the known CCK antagonists, Devazepide or lorglumide proved to be clinical useful, which is in line with our results.
Table 4: Cytotoxicity assay, $\mathrm{IC}_{50}$ of selected examples against a variety of $\mathrm{GI}$ and brain cell lines $\mathrm{IC}_{50}$ values are based on inhibition of viability in the MTT assay in various cell lines.

\begin{tabular}{|c|c|c|c|c|}
\hline $\begin{array}{c}\text { IC }_{\mathbf{5 0}} \\
\text { [nM] }\end{array}$ & MIA PACA & PANC & MAC13 & MAC16 \\
\hline L-365,260 & $>5000$ & $>1000$ & $>5000$ & $>5000$ \\
\hline Devazepide & 1200 & $480 \pm 32$ & 1100 & 1000 \\
\hline Lorglumide & $425 \pm 23$ & $316 \pm 21$ & $421 \pm 11$ & $861 \pm 22$ \\
\hline PNB-081 & $15 \pm 4$ & $27 \pm 9$ & $536 \pm 32$ & $96 \pm 25$ \\
\hline PNB-028 & $11 \pm 4$ & $18 \pm 6$ & $508 \pm 35$ & $76 \pm 20$ \\
\hline Cl-lactam & $13 \pm 4$ & $22 \pm 9$ & $526 \pm 34$ & $86 \pm 23$ \\
\hline
\end{tabular}

PANC: The PANC cell line is a human pancreatic cell line. PNB-081 and PNB-028 are many times better than Devazepide/ lorglumide on this selected pancreatic cell line. Cancer treatment is combination therapy, even for hormone dependent cancers. For this pancreatic cell line the synergistic effects of MK-329=Devazepide in conjunction with Cisplatin were reported [24-26] and studies to 
investigate PNB-028 with Cis - platin and 5-FU are ongoing. Overall, the isobutyl pyrrolone were not significantly different from each other and PNB-81 as well as the halogenate fluorinated PNB-028 were tested subsequently in vivo in xenograft models. In vitro in cell based assays they were found of equal selective toxicity towards 2 human pancreatic and 2 colon cancer cell lines. The cytotoxicity results for CCK related cell lines are outlined in with lorglumide and Devazepide as CCK 1 standard and L-365,260 as CCK $_{2}$ standard.

MAC 16: MAC 13 and MAC 16 cancers are derived from the colon of the mouse and MAC 16 is of particular interest, as it is resistant to alkylating agents. For PNB-081, an $\mathrm{IC}_{50}$ about $100 \mathrm{nM}$ was determined for the MAC 16 cell line and the fluorinated analogue PNB-028 was slightly more potent. Most interestingly, no other CCK antagonist, such as L-365,260, Devazepide or lorglumide was found active for this cell line, which is, when transplanted into mice lethal within weeks. Therefore, it may be concluded, that the insurmountable irreversible properties of the antagonists are key to colon cancer. Subsequently, this MAC 16 tumour was studied initially in mice to analyse, if the in vitro results can be translated into relevant anti-tumour activity.

\section{Animal studies in mice}

Cholecystokinin is known to mediate cancer progression and metastasis, which were antagonised by sufficient concentrations of Devazepide [27]. One animal in vehicle-treated group died during the course of the study, which is typical for MAC 16 induced cancer, showing the lethality of this selected cancer model.

\section{Allograft colon cancer in vivo study}

MAC 16 tumours developed quickly within 6 days after implantation and grew robustly. Once the tumours reached $100 \mathrm{~mm}^{3}$, the animals were divided into the various treatment groups and treated with vehicle or the fluorinated PNB-028. Isobutylated pyrrolone inhibited the tumour growth significantly from the day treatment was initiated and maintained tumour inhibitory activity until sacrifice. At sacrifice, interestingly in some animals growth was not only inhibited, but tumours shrinked after reaching a maximum volume. Most interestingly, while MAC 16 tumours in the vehicle-treated group metastasized to lungs, tumours in drugtreated groups did not metastasize to lungs.

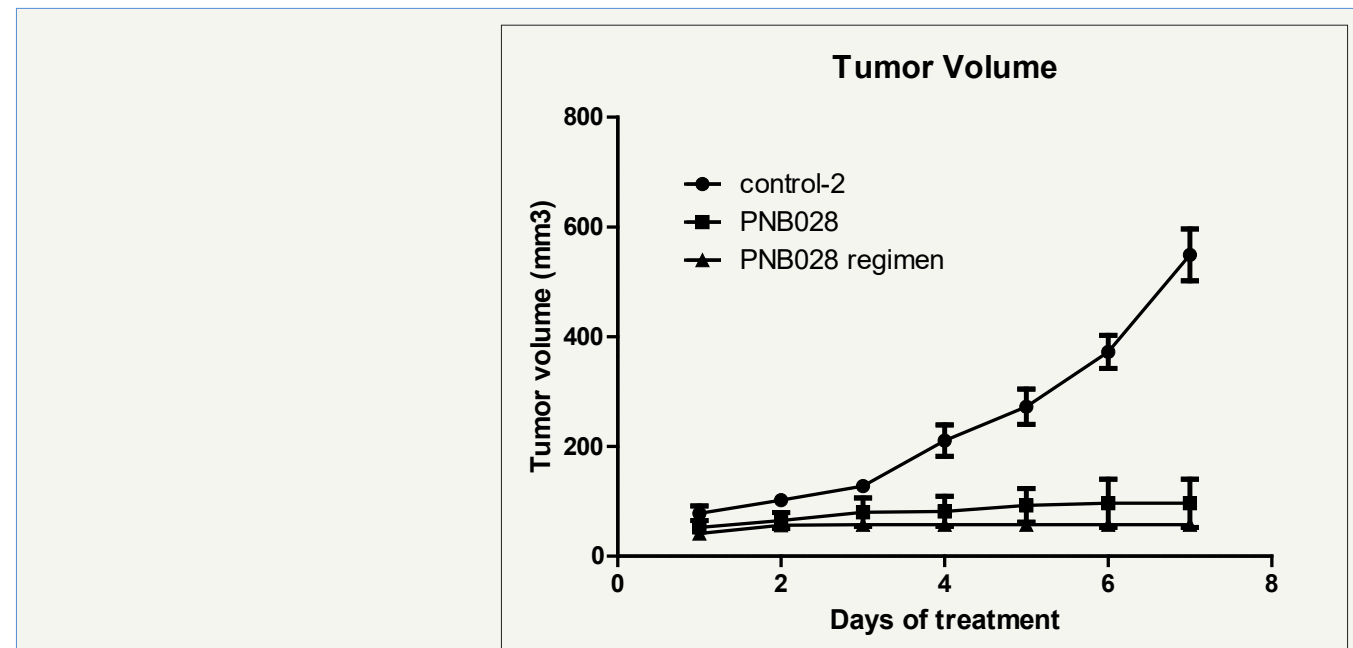

Figure 8a: Tumour volume in mice for the treatment with PNB-028 over the period of 7 days.

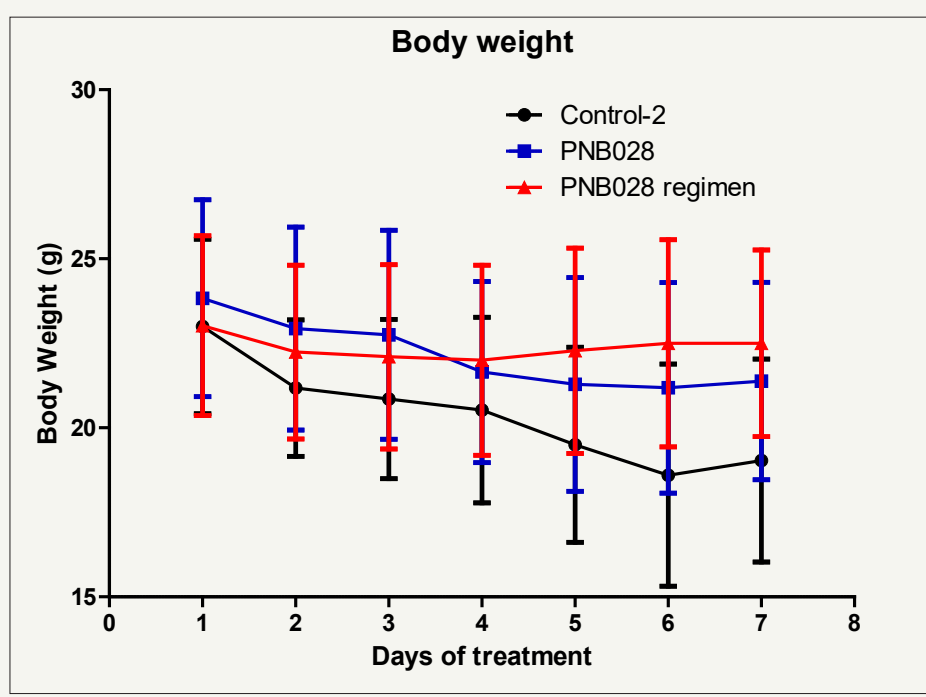

Figure 8b: Body weight loss during PNB-028 treatment in mice over the period of 7 days. 
The control showed nearly exponential growths for this aggressive tumour. The treatment group by oral administration at optimum level $(100 \mathrm{mg} / \mathrm{kg})$ showed strong inhibition of tumour growths and the regiment study with bi-daily instead of daily dosing intervals (24h-48h) with a calculated daily dose of 50mg/ $\mathrm{kg}$ showed enhanced activity and reduced toxicity (Figure $8 \mathrm{a}$ ) The analysis of body weight showed an expected loss of $20 \%$, which lead to termination at day 7 in the control group and for the $48 \mathrm{~h}$ regimen even an increase of body weight was found (Figure $8 b$ ). Cholecystokinin is known to mediate cancer progression and metastasis, which were antagonised by sufficient concentrations of Devazepide [27] in vivo in mice, but translation failed clinically as inhibition was reversible with Devazepide and the receptor occupancy was also insufficient. Colon cancer is generally linked with the $\mathrm{CCK}_{1}$ receptor and only under certain conditions it is associated with the $\mathrm{CCK}_{2}$ receptor [28]. Colucci tested only one $1 \mathrm{nM}$ concentration of Devazepide, which stimulated growths in the study and by our own observations. Overall for the MAC 16 cell line proliferation was blocked in vitro and in vivo by PNB-028. Here, the link $\mathrm{CCK}_{1}$ receptor and colon cancer was confirmed experimentally. Efforts to elucidate the underlying anticancer action were made and no significant apoptosis and no influence on angiogenesis by angiogenesis marker CD34, was observed. Proliferation, analysed by proliferation marker KI67, was performed and the results were outlined in Figure 9.

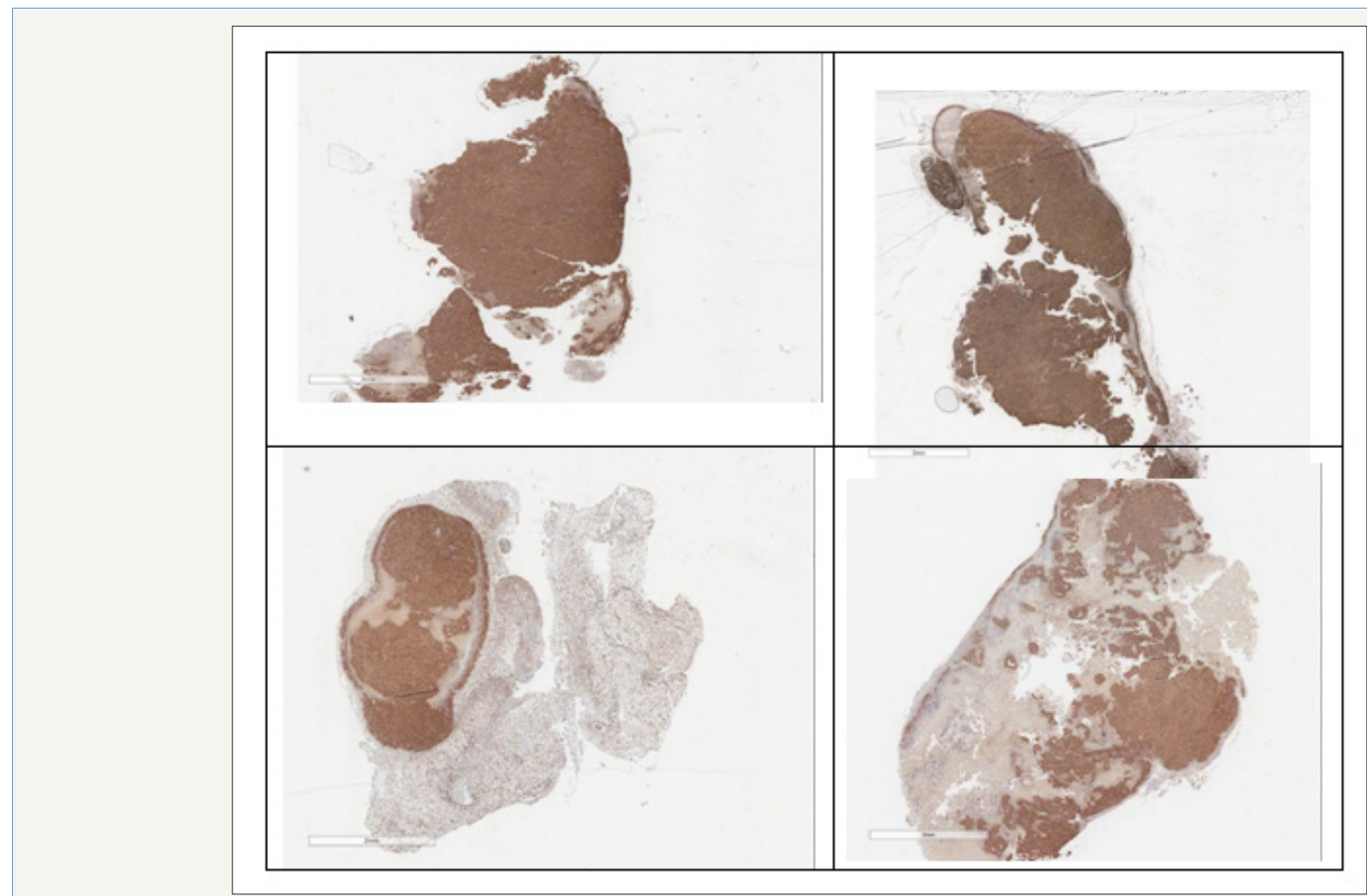

Figure 9: Histology Ki67 staining: top control, bottom PNB-028 treated 50mg/kg by PO administration.

For the minimal dose of $50 \mathrm{mg} / \mathrm{kg}$ in mice, the tissue was stained (TOP) and in the treatment group large white areas of proliferation free tissue was seen (Figure 9). These findings are particularly important for the understanding of the standard colon cancer biomarker CEA. Dell death, as a result of apoptosis caused by $\mathrm{Pt}$ agents and antimetabolite 5-FU resulted in an increase of biomarker CEA, followed by a decline from week 4 onwards in man. The cell lines differ in CCK expression and the selected pancreatic cancer cell line in vivo has some expression of the cholecystokinin receptor.

\section{MIAPACA tumour xenograft study}

MIAPACA tumours developed quickly after implantation and grew modestly, though not as robustly as MAC 16 tumours. Once the tumours reached $100 \mathrm{~mm}^{3}$, the animals were divided into various treatment groups and were treated with vehicle or respective drugs.
Though vehicle-treated MIAPACA tumours grew from $100 \mathrm{~mm}^{3}$ to over $750 \mathrm{~mm}^{3}$ within 3 weeks, pyrrolone treated tumours grew slower. Both agents inhibited tumour growth significantly from the day treatment was initiated and maintained the growth inhibitory properties until sacrifice (Figure 10). Overall, it was clearly shown, that colon and pancreatic cancers response to $\mathrm{CCK}_{1}$ antagonists and not $\mathrm{CCK}_{2}$ antagonists [29]. We agree, it is unlikely that, Gastrin is more important in pancreatic cancer than cholecystokinin. PNB028 was clearly more efficient in colon cancer, based on the MAC16 murine colon cancer cell line. For pancreatic cancer the results are even more interesting when the oral bioavailability is considered. It may be wise to say, that it is pancreozymin, via the pancreatic cholecystokinin receptor, that promotes cancer or possibly the CCK-C receptor. Smith clearly stated the role of the CCK-C receptor in pancreatic cancer [30] and reviewed the cholecystokinin receptor as molecular target in treating pancreatic cancer [31]. 


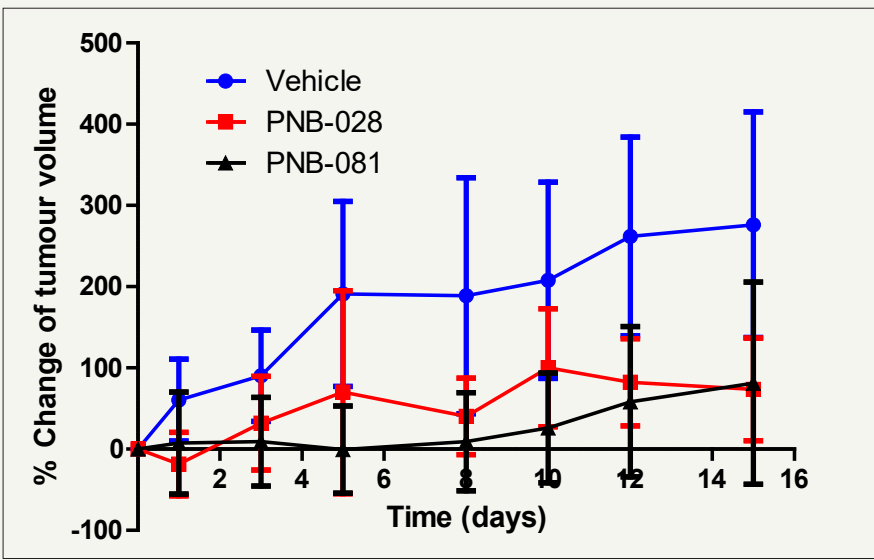

Figure 10: Effect of PNB molecules on MIAPACA pancreatic cancer tumour growth.

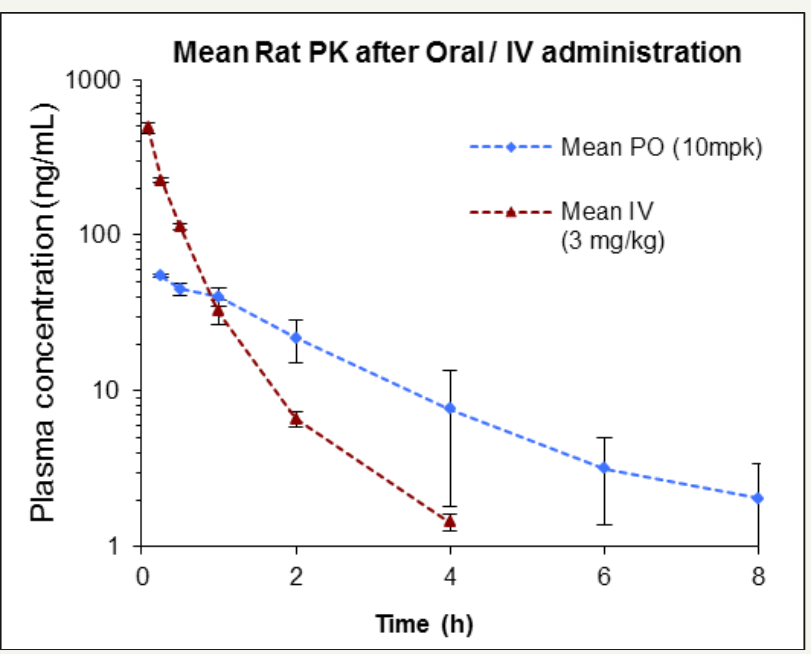

Figure 11: Kinetics of PNB-081.

If it is the CCK-C receptor, then this molecular target would antagonist best in the treatment of cancer as the $\mathrm{CCK}_{1}$ receptor is required for the physiological role of cholecystokinin. Blocking of the contractions of the gall bladder leads to gallstones in the long term and reductions of bile flow will result generally in liver toxicity. For lactam PNB-081 an oral bioavailability was determined as $24 \%$ in rats for the $10 \mathrm{mg} / \mathrm{kg}$ dose. PNB-028 had $98 \%$ oral bioavailability and represents the $\mathrm{CCK}_{1}$ antagonist with the highest known bio-availability of all published molecules. The analysis of the plasma concentration in rats was analysed for PNB-081 (24\%) and is outlined in Figure 11.

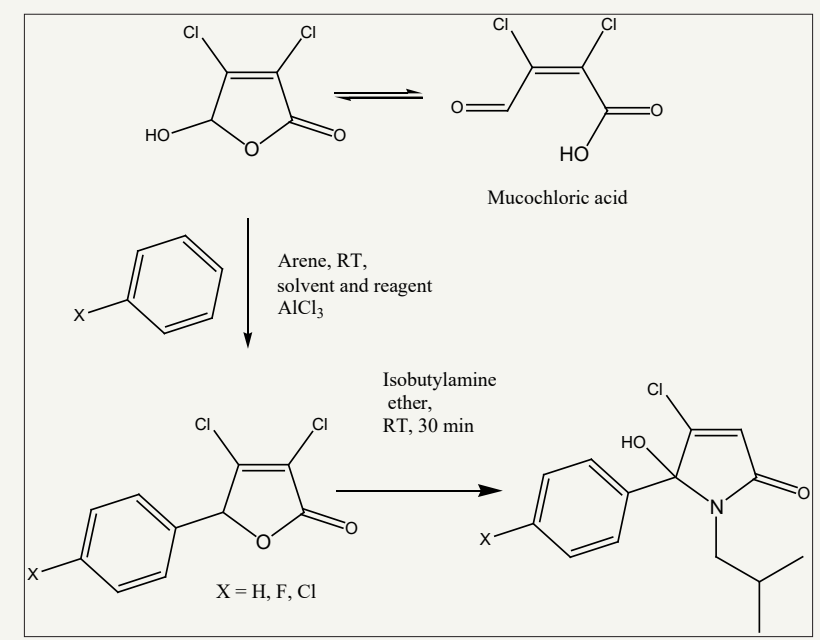

Figure 12: Synthesis of arylated lactams. PNB-028: $\mathrm{X}=\mathrm{F}, \mathrm{PNB}-081: \mathrm{X}=\mathrm{H}$. 
The isobutyl group, as aliphatic side chain, is inert towards metabolism and the bioavailability for PNB-081 is medium with $24 \%$. After the introduction of a fluorine atom in PNB-028 a nearly full oral bioavailability was achieved. This CCK antagonist occurred the best bioavailability compared to present competitors and will enable us the achieve plasma concentrations to shut down CCK mediated cancer growths pathways (Figure 12).

PNB-028 was best agent in murine colon cancer models and the results for pancreatic cancer under the consideration of plasma require further analysis. In nude mice both agents are not significantly different, but apparently PNB-081 is giving higher inhibitions. Considering the 4 times higher bioavailability of PNB028 over PNB-081 this effect should be achieved by only a quarter of the dose. So, based on a bell shaped dose response curve known for CCK antagonists, a dose reduction may have given the same or even better effect, similar to the effect observed in MAC16 models.

\section{Conclusion}

This novel arylated hydroxyl-pyrrolone template was synthesised in only 2 synthetic steps in high overall yields from readily available starting material. For the potent $\mathrm{CCK}_{1}$ ligands, a full non-competitive, possible irreversible CCK antagonism was confirmed classically, using isolated tissue preparations, which is ideal for an antineoplastic agent. For this novel template, it was found, that CCK antagonism translated into anti-cancer activity within the GI system and the known CNS activity of CCK antagonists may be of additional therapeutic benefit in treating cancer associated diseases. The isobutyl series stopped the growths of colon- and pancreatic cancer models. A full pre-clinical development programme was completed for PNB-028 and IND documents were submitted to launch a combined first in man clinical trial in patients at Lambda in India.

\section{Acknowledgement}

The experimental work was partly supported by PNB Vesper Life Sciences. No conflict of interest is declared. The animal studies were performed in compliance with relevant laws and institutional guidelines.

\section{References}

1. McDonald IM (2001) $\mathrm{CCK}_{2}$ receptor antagonists. Exp Opin Ther Patents 11: 445-462.

2. Bock MG, DiPardo RM, Mellin EC, Newton NC, Daniel F, et al. (1994) Second-generation benzodiazepine CCK-B antagonists development of sub nanomolar analogs with selectivity and water solubility. J Med Chem 37(6): 722-724.

3. Jorpes E, Mutt V (1966) Cholecystokinin and pancreozymin one single hormone? Acta Physiologica Scandinavica 66(1): 196-202.

4. Bradwejn J, Koszycki D, Meterissian G (1990) Cholecystokinin tetra peptide induces panic attacks in patients with panic disorder. Can Psychiatry 35(1): 83-85.

5. Lattmann E, Arayarat P (2003) Review article: From CNS-drugs to antineoplastic agents: Cholecystokinin (CCK)-antagonists as modern anticancer agents. Science (KKU) 31: 178-193.

6. Dourish CT, Ravard S (1990) Cholecystokinin and anxiety. Trends Pharmacol Sci 11(7): 271-273.
7. Rasmussen K, Czachura JF, Stockton ME, Howbert J (1993) Electrophysiological effects of di phenyl pyrazolidinone cholecystokinin-B and cholecystokinin-A antagonists on midbrain dopamine neurons. J Pharmacol Exp Ther 264(1): 480-488.

8. Dourish CT, Rycroft W, Iversen SD (1989) Postponement of satiety by blockade of brain cholecystokinin (CCK-B) receptors. Science 245(4925): 1509-1511.

9. Trivedi BK (1994) Curr Med Chem 1: 313.

10. Lattmann E, Billington DC, Poyner D R, Howitt SB, Offel M (2001) Synthesis and evaluation of Asperlicin analogues as non-peptidal cholecystokinin antagonists. Drug Des Discov 17(3): 219-230.

11. Evans BE, Rittle KE, Bock MG, DiPardo RM, Freidinger RM (1988) Methods for drug discovery development of potent selective orally effective cholecystokinin antagonists. J Med Chem 31(12): 2235-2246.

12. Abbruzzese JL, Gholson CF, Daugherty K, Larson E, DuBrow R, et al. (1992) Pancreas 7: 165

13. Orikawa Y, Kato H, Seto K, Kobayashi N, Yoshinaga K, et al. (2010) Z-360, a novel therapeutic agent for pancreatic cancer, prevents upregulation of ephrin $\mathrm{B} 1$ gene expression and phosphorylation of NR2B via suppression of interleukin-1 $\boldsymbol{\beta}$ production in a cancer induced pain model in mice. Mol Pain 6: 72.

14. Meyer T, Caplin ME, Palmer DH, Valle JW, Larvin M, et al. (2010) A phase Ib/IIa trial to evaluate the $\mathrm{CCK}_{2}$ receptor antagonist Z-360 in combination with gemcitabine in patients with advanced pancreatic cancer. Eur J Cancer 46(3): 526-533.

15. Makovec F, Chistè R, Bani M, Pacini MA, Setnikar I, et al. (1985) Drug Res 35: 1048.

16. Offel M, Lattmann P, Singh H, Billington DC, Bunprakob Y, et al. (2006) Archiv der Pharmazie chemistry in Life Science 339: 163.

17. Lattmann E, Singh H, Boonprakob J, Lattmann P , Sattayasai J (2006) Synthesis and evaluation of N-(3-oxo-2,3-dihydro-1H-pyrazol-4-yl)-1Hindole-carboxamides as cholecystokinin antagonists. J Pharm Pharm 58(3): 393-401.

18. Lattmann E, Sattayasai J, Boonprakob J, Lattmann P, Singh H (2005) Synthesis and evaluation of N-(5-methyl-3-oxo-1,2- diphenyl2,3-dihydro-1H-pyrazol-4-yl)- $\mathrm{N}^{\prime}$ phenylureas as cholecystokinin antagonists. Arzneim Forsch Drug Research 55(5): 251-258.

19. Lattmann E, Sattayasai J, Boonprakob Y, Singh H, Lattmann P (2008) Cholecystokinin antagonists (part 1): Antinociceptive anxiolytics and antidepressant effects of N-(5-methyl-3-oxo-1,2-diphenyl-2,3-dihydro$1 \mathrm{H}$-pyrazol-4-yl)-N'-phenylureas and carboxamides. Drug Discov Ther 2(3): 156-167.

20. Lattmann E, Billington DC, Poyner DR, Arayarat P, Howitt SB, et al. (2002) Combinatorial solid phase synthesis of multiply substituted 1,4-benzodiazepines and affinity studies on the $\mathrm{CCK}_{2}$ receptor. Drug Des Discov 18(1): 9-21.

21. Lattmann E, Sattayasai J, Billington DC, Poyner DR, Puapairoj P, et al. (2002) Synthesis and evaluation of N1-substituted-3-propyl-1,4benzodiazepine-2-ones as cholecystokinin $\left(\mathrm{CCK}_{2}\right)$ receptor ligands. J Pharm Pharm 54(6): 827-834.

22. Lattmann E, Lattmann P, Singh H (2004) (Aston University) W02004106315A3.

23. Lattmann E, Ayuko W, Kinchinaton D, Langley CA, Karimi L, et al. (2003) Synthesis and evaluation of 5-arylated $2(5 \mathrm{H})$-furanones and 2-arylated pyridazin-3(2H)-ones as anti cancer agents. J Pharm Pharm 55(9): $1259-1265$

24. Jamshidipour R, Pinho EB, Hom DK, Howell SB (1994) Cancer Chemother Pharmacol 34: 484 .

25. Reubi JC, Schaer JC, Waser B (1997) Cholecystokinin (CCK)-A and CCK-B/ Gastrin receptors in human tumors. Cancer Research 57(7): 1377-1386. 
26. Oikonomou E, Buchfelder M, Adams EF (2008) Neuropeptides 42: 255.

27. Matters GL, Cooper TK, McGovern CO, Gilius EL, Liao J, et al. (2014) cholecystokinin mediates progression and metastasis of pancreatic cancer associated with dietary fat. Dig Dis Sci 59(6): 1180-1191.

28. Colucci R, Blandizzi C, Tanini M, Vassalle C, Breschi MC, et al. (2005) Gastrin promotes human colon cancer cell growth via CCK-2 receptormediated cyclooxygenase-2 induction and prostaglandin E2 production. Br J Pharmacol 144(3): 338-348.
29. Matters GL, McGovern C, Harms JF, Markovic K, Anson K, et al. (2011) Int J Oncol 38: 593

30. Smith JP, Stanley WB, Verderame MF, Zagon IS (2004) The functional significance of the cholecystokinin-C (CCK-C) receptor in human pancreatic cancer. Pancreas 29(4): 271-277.

31. Smith JP, Solomon TE (2014) Am J Physiol Gastrointest Liver Physiol 306: 91. (c) (i) Creative Commons Attribution 4.0

For possible submissions Click Here
Submit Article

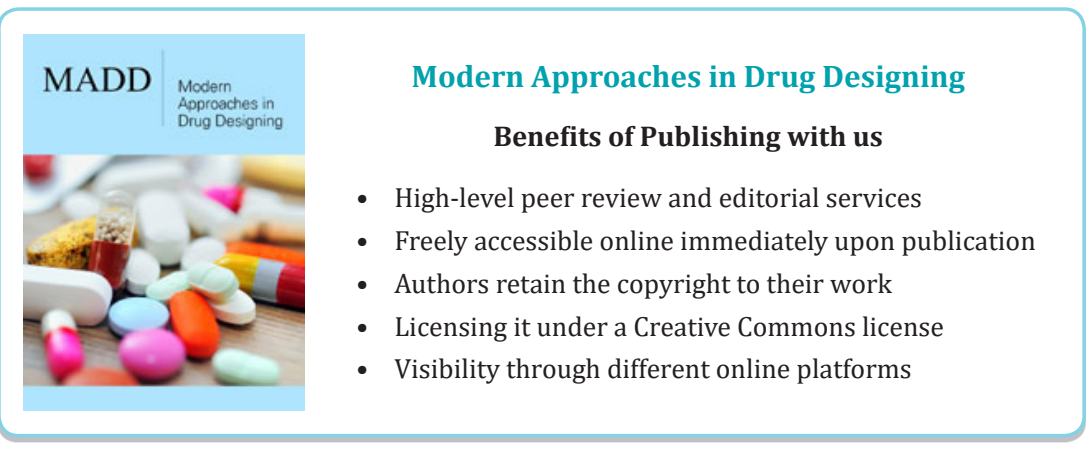

